\title{
PROMOTING TEMPE AS INDONESIAN INDIGENEOUS FOOD AND CULTURE
}

\author{
Dadi Maskar ${ }^{1 *}$, Khoirul Anwar ${ }^{1}$, Nindy Sabrina ${ }^{1}$, Astawan Made $^{2}$, Hardinsyah Hardinsyah ${ }^{3}$, Naufal M \\ Nurdin $^{4}$, Shanti Pujilestari ${ }^{1}$ \\ ${ }^{1}$ Nutrition Study Program, Sahid University - Jakarta; ${ }^{2}$ Indonesia Tempe Forum, ${ }^{3}$ Food Nutrition \\ Society of Indonesia, ${ }^{4}$ Community Nutrition Department, Bogor Agricultural University \\ "dadi_maskar@usahid.ac.id
}

\begin{abstract}
Tempe is an indigenous food from Indonesia. Historical evidence show that soybean tempe originated in Central Java and appeared in the Javanese food culture around five centuries ago. Until recently, little attention has been paid to promote tempe even it contributes significantly to the nutrient intake of Indonesians and could prevent hypercholesteremia and hyperglycaemia. This activity aimed at promoting Tempe as Indonesian Indigenous food and culture; and gaining the support from professional organizations, government, community, producers and consumers in order to include tempe in the national list of intangible cultural heritage. This activity was held since 2015 till 2018. The way to promote it was through seminars, online and offline support, and competition. During the last three years, fifteen seminars on the health of tempe were done in fifteen cities covered 4500 women leaders, scientist and government officers. Information about culture and health benefit of tempe was also promoted through social media, and competition, as well as online petition. As much as 22 related professional association, central government institutions, universities, tempe producers and consumers supported written that tempe should be proposed to be national list of intangible cultural heritage; and further to be intangible cultural heritage of UNESCO. The final result of this activity was the Ministry of Education \& Culture formally launched that tempe was included in the list of national list of intangible cultural heritage based on certificate number 60089/MPK.E/KB/2017. Besides, tempe also include among the five unique indigenous culture to be promoted to be and intangible cultural heritage of UNESCO.
\end{abstract}

Keywords: Cultural heritage, indigenous food, Indonesian food, tempe culture

\section{INTRODUCTION}

Tempe is an indigenous food from Indonesia. Historical evidence show that soybean tempe originated in Central Java and appeared in the Javanese food culture around five centuries ago.It is made by a unique process, discovered many centuries ago by the ancestors of the Indonesian, and is now familiar to many people in different nations. The local name of tempe is now recognized internationally and can be used for international and regional publications as there are no other common English name for this product.Tempe, tofu, soy milk, and other soybean products have been widely consumed since a long time ago and become important protein sources for Indonesian. According to The National Economic Survey (Survei EkonomiNasional/Susenas) 2009, tempe, tofu and sweet soy sauce was consumed by $69.89 \%, 63.72 \%$ and $42.5 \%$ households in Indonesia, respectively, indicating a high consumption. Average daily consumption of tempe is $30 \mathrm{gr} /$ person (Statistics Indonesia, 2014). In 2015, Indonesian total soybean consumption was 2.5 million tons per year, in which more than $70 \%$ of the soybean was imported (Statistics Indonesia, 2015). Until recently, little attention has been paid to promote tempe even it contributes significantly to the nutrient intake of Indonesians and could prevent Hypercholesterolemia and hyperglycaemia (Utari et al. 2011; Bintari et al. 2015; Wirawanti et al. 2017).

Nowadays, tempe has been known and produced in more than 20 countries, mainly produced in industrial scale. This fact encouraged the establishment of international trading standard regarding tempe, which was regulated in CODEX STAN 313R-2013. With the growing popularity of tempe 
worldwide, we inclined to propose tempe to UNESCO as Intangible Cultural Heritage of Humanity. This is very important thing to do, with four main reasons, which is: a) Preserve Intangible Cultural Heritage of Humanity (ICHH). This activity will motivate all stakeholders related to tempe (soybean farmer, tempe crafters, academics authorities, industrial sectors, and governments) to be more aware and more active in preserving the culture of tempe; b) Ensuring the homage to Intangible Cultural Heritage; c) Raising awareness in local, regional, national, and international level regarding the importance of tempe and its health benefit; and d) Regulates the International cooperation. Acknowledgement to tempe will motivate related organizations and stakeholders to improve international cooperation regarding the culture of tempe. This activity aimed at promoting Tempe as Indonesian Indigenous food and culture; and gaining the support from professional organizations, government, community, producers and consumers in order to include tempe in the national list of intangible cultural heritage.

\section{THEORETICAL FRAMEWORK}

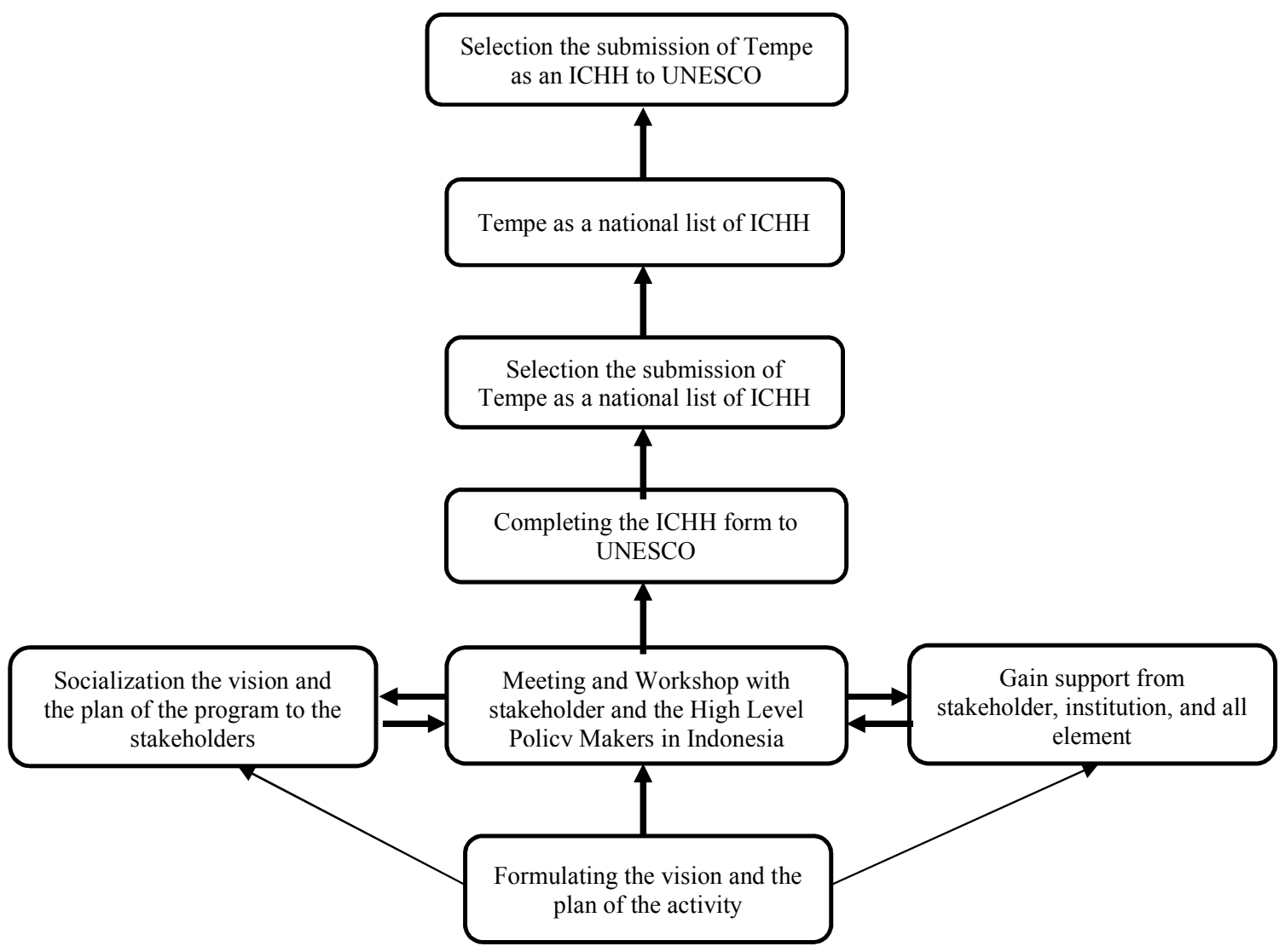

Figure 1. Theoritical framework of promoting tempe as indonesian indegeneous

\section{METHOD}

\section{Time and Location}

This activity was held since 2015 till 2018. The way to promote it was through seminars, online and offline support, and competition. During the last three years, fifteen seminars on the health of tempe were done in fifteen cities covered 4500 women leaders, scientist and government officers. Information about culture and health benefit of tempe was also promoted through social media, and competition, as well as online petition. As much as 22 related professional association, central government institutions, universities, tempe producers and consumers supported writenly that tempe should be proposed to be national list of intangible cultural heritage; and further to be intangible cultural heritage of UNESCO. 
Activities

There are many activities that have been carried out as an effort to propose tempe as ICCH to UNESCO, such as :

a. Discussion and workshop on formulating the vision and the plan of the program

This meeting discussed the proposal to sponsor and formulation of action plan, which was part of the steps towards submission Tempe as ICHH. Also the target for this this activity. Workshops with stakeholders were also carried out to finalize the activity plan

b. Produce socialization/education media such as Tempe Batik

The competition for the community of Indonesia especially young generation was conducted to create the Batik Tempe design in order to socialize the submission of Tempe as ICHH.

c. Socialization the vision and the plan of the program through social media, press conference and seminars

The vision and the plan regarding the submission of Tempe as ICHH were socialized through social media.To further socialize the plans and goals of this program, a press release was also madethat inform to establishing of Tempe as ICHH from Indonesia in national list. To further socialize the plans and goals of this program, the committe held the national seminar in Bogor.

d. Meeting with local stakeholders form all levels

The meeting with local stakeholders from all levels in central and east java, and ministry of education and culture.

e. Collecting documents, photos, artifact, video of tempe

In order to submission Tempe as Intangible Cultural Heritage of Humanity (ICHH)-Indonesia, need to prepare UNESCO's documents. The document must be filled as a required submission of Tempe to UNESCO.

f. Stakeholder Workshop to finalize the 13 forms of UNESCO on Intangible cultural heritage According to the recognition of the ICHH from Indonesia, held by The Ministry of Education and Culture, Tempe has been decided as a ICHH from Indonesia in national list.

g. Gain support from stakeholder, institution, and all elements

Gaining support from stakeholder, institution, and all elements is necessary to be done so that the submission of tempeh as an ICHH to UNESCO

\section{RESULT AND DISCUSSION}

Discussion and workshop on formulating the vision and the plan of the program

This meeting discussed the proposal to sponsor and formulation of action plan, which was part of the steps towards submission Tempe as ICHH. Also the target for this this activity. Workshops with stakeholders were also carried out to finalize the activity plan. The target for 2018 that was achieved Tempe to as a national list of ICHH from Indonesia. Gaining written support was also planned from all elements to support Tempe as ICHH to UNESCO. The other targets are Meeting and Workshop with the High-Level Policy Makers in Indonesia, prepare the Tempe document for the inscription on the representative list of Indonesian intangible cultural heritage for humanity to UNESCO, and produce socialization/education media such as Tempe Batik.
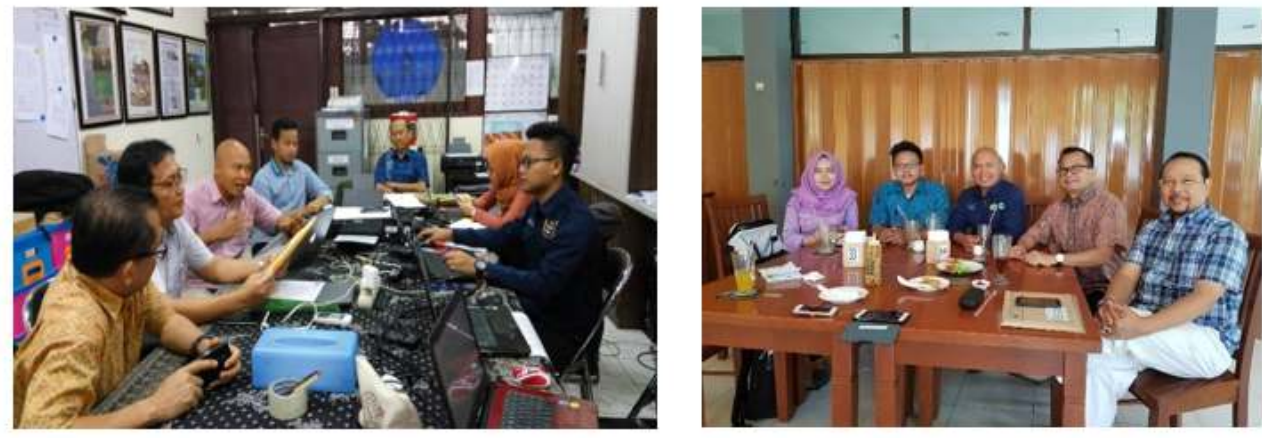
Figure 2. Discussion and workshop on formulating the vision and the plan of the program

A stakeholder workshop was held in SEAFAST CENTER, Bogor Agricultural University, and Taman Koleksi, Bogor, which were attended by experts on food and nutrition, consisting of Head of PERGIZI PANGAN, and also Head of Forum Tempe Indonesia. The things which were scheduled on this Workshop are the report of establishing Tempe as ICHH to Ministry of Education and Culture as ICHH. Tempe was established as ICHH in the national list of Indonesia. Cultural and Education Department of Central Java Province in collaboration with PERGIZI PANGAN Indonesia and Indonesia Tempe Forum prepare the recognition of Tempe as ICHH Indonesia to UNESCO. In this workshop, the committee and expertise formulate the best strategies also the timeline to propose Tempe to UNESCO as ICHH from Indonesia and completing the document. Intangible Heritage can be established as ICHH with criteria such as: symbolizing the identity of Indonesian culture; have an important value for Indonesia; can be accepted by all Indonesian; have a culturist value which will raise the awareness regarding the nation's unity and identity; and have diplomatic value. Regional government has the authority to submit intangible culture to Directory of Cultural Heritage and Diplomacy, General Directorate of Culture, Ministry of Education and Culture.

\section{Produce socialization/education media such as Tempe Batik}

The competition for the community of Indonesia especially young generation was conducted to create the Batik Tempe design in order to socialize the submission of Tempe as ICHH. This activity was done in order to explore ideas from the community and also to promote Tempe using new way. More than 30 designs were submitted to the committee. Then the committee selected it into 5 best design (best design and the philosophy attached). The theme of this contest was "Tempe as ICHH from Indonesia to the world". After that, Tempe Batik was produced to promote the Tempe as ICHH of Indonesia.
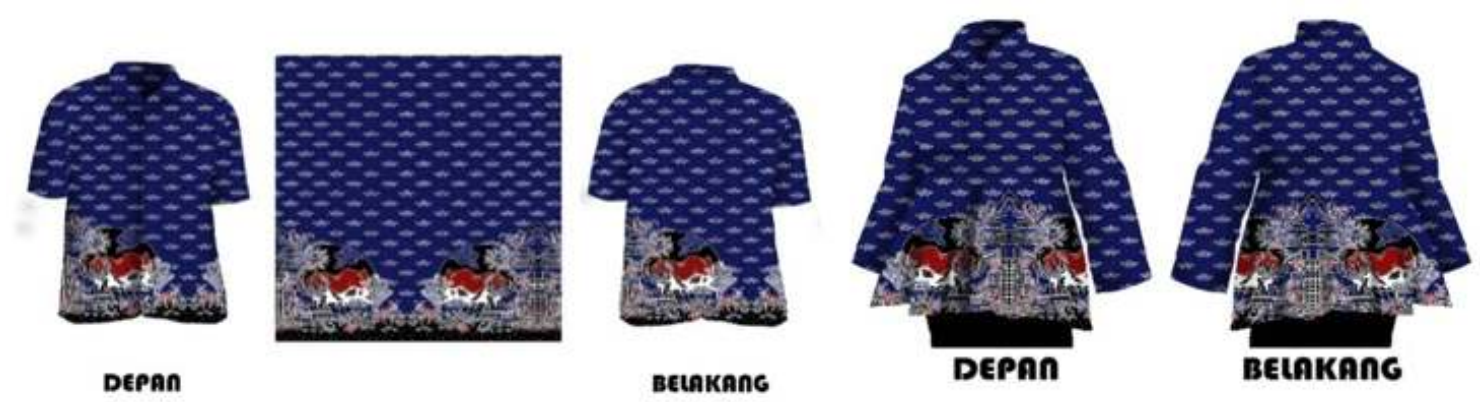

Figure 3. Tempe Batik to Promote the Tempe as ICHH

\section{Socialization the vision and the plan of the program through social media, press conference and seminars}

The vision and the plan regarding the submission of Tempe as ICHH were socialized through social media. To further socialize the plans and goals of this program, a press release was also madethat inform to establishing of Tempe as ICHH from Indonesia in national list. To further socialize the plans and goals of this program, the committe held the national seminar in several cities.

The vision and the plan regarding the submission of Tempe as ICHH were socialized through social media. Besides that, we would've socialized that Tempe has accepted as ICHH from Indonesia by Ministry of Cultural and education of Indonesia. The submission of a certificate was held on Oct 4th, 2017 in Jakarta. From this socialization, our goals and plans regarding the submission of Tempe as ICHH can be known widely by all of Indonesian.

To further socialize the plans and goals of this program, the seminar and training was held in Bogor, Jember, Malang, and Semarang. The objectives of this seminar and training were to socialize the progress of the nomination of Tempe to UNESCO, also to improve the science information about Tempe. 

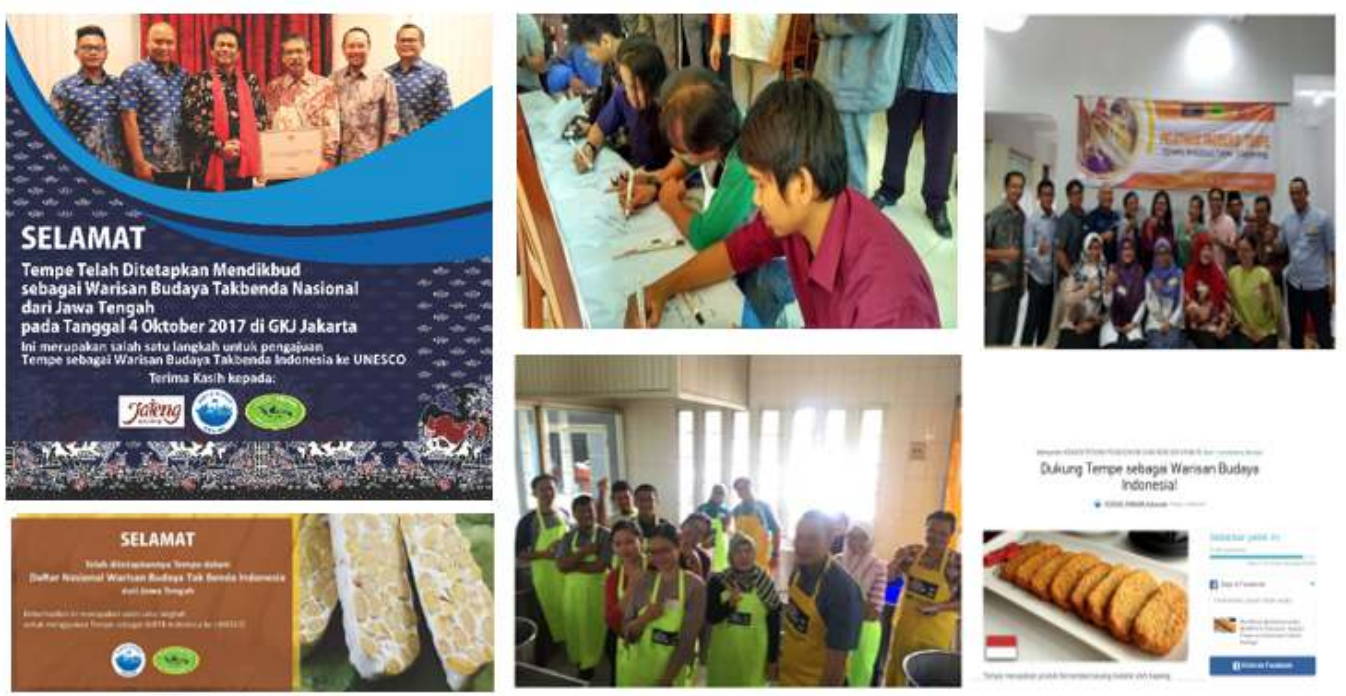

Figure 4. Socialization the the activity through social media, press conference and seminars

\section{Meeting with local stakeholders from all level}

The meeting with local stakeholders in central and east java has be done in Semarang, Klaten, Yogyakarta, Gunungkidul, Malang, and Surabaya. Besides that the committee also met the expertise of culture in Yogyakarta that learn about Tempe and Javanese Culture. According to the meeting, we get the information that Tempe was from Java, and there are the many function of Tempe in communities include the cultural function. For example, Tempe was be used as a "sesajen" to the Traditional Ceremonies in Javanese people. Tempe also has the deep meaning for the culture, such as "Tempe Bacem" mean "Happiness", and the process of the production of Tempe mean "the harmonious relationship in the family between husband and wife".
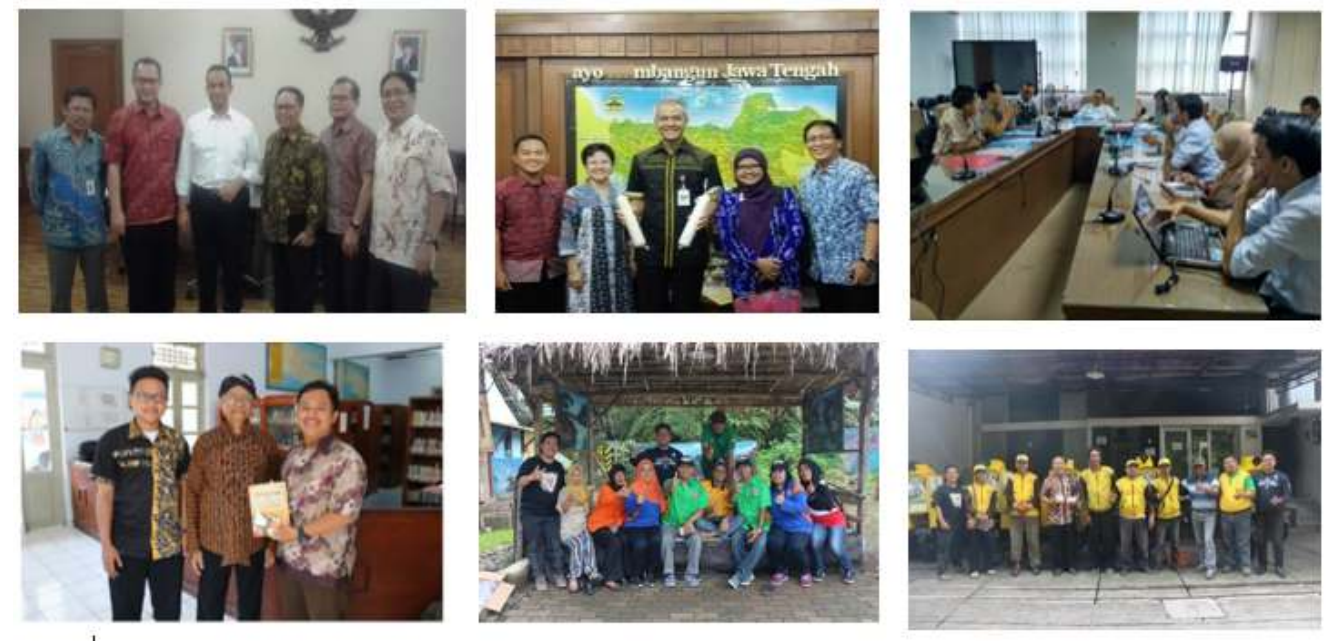

Figure 5. Meeting with local stakeholders from all levels

\section{Collecting documents, photos, artifact, video, etc of tempe}

In order to submission Tempe as Intangible Cultural Heritage of Humanity (ICHH)-Indonesia, need to prepare UNESCO's documents. The document must be filled as a required submission of Tempe to UNESCO. In order to fill the document, it was needed some information especially on the cultural aspect of Tempe. Based on these considerations, the committee need to go to Klaten and Yogyakarta (suspected as a place of origin Tempe). The team asked the elder figure, experts, and also local 
government to get the information. The committee got several books that describe Tempe and local culture in ancient times.In this activity, the committee got the documents, photos, artifacts, video that correlate with Tempe as a culture in Javanese people. We can conclude that Tempe was originally produced from black soybeans, originating in the traditional societies of rural areas of Java, certainly before 16th century. The data indicated that it developed in the Mataram region of central java. Although there are several different ways of preparing Tempe, they share the same basic technology of preparing soybeans by soaking and cooking to produce a suitable substrate to support fungal growth and fermentation.
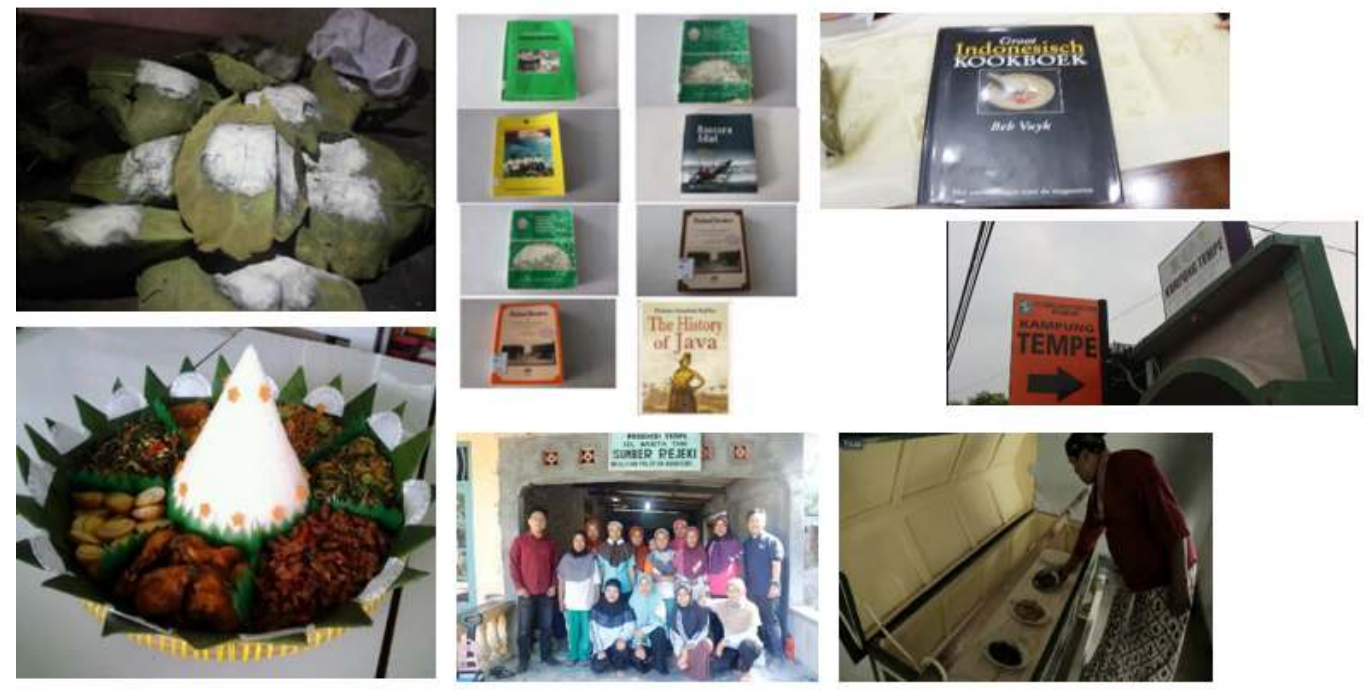

Figure 6. Collecting documents, photos, artifact, video, etc of tempe

There are some books that mentionthe function of Tempe as a "sesajen" in traditional ceremonies of Javanese people. That books were: Java Cuisine in SeratCenthini (Kuliner Jawa dalam serat centhini); Food in form, variation, function and way to presentation of Javanese people of Yogyakarta (MAKANAN, wujud, variasi dan fungsinya serta cara penyajiannya pada orang jawa DIY); Traditional ceremony to get the rain in Kepuharjo Village (Upacara Tradisional Mohonhujan di Desa Kepuharjo, Kec Cangkringan, Kab Sleman DIY); The traditional ceremonies in Yogyakarta (Upacara Tradisional sebagai kegiatan sosialisasi DIY); The report of JARAHNITRA (Laporan Penelitian JARAHNITRA). Tempe is a food that is used for special events, such as Jadah tempe consisting of jadah and Tempe bacem that serves pleasure. In addition, Tempe is also used for traditional ceremonies such as: nglimani ceremony (baby 5 months in mother's womb), brokohan ceremony (baby birth), tahlilan, surtanah (death memorial ceremony), matang puluh dina ( $40^{\text {th }}$ anniversary of death), nelung-dinani ceremony (3 days after death), ceremony for rain or becekan, jolosutro ceremony (ie clean village ceremony or rasulan or kupatan), and ceremony of rebowekasan, and sedekahbumi.

The other results were Tempe closely related to community life because soy is a plant that can be planted in a flexible soil (relatively easy); The process of making soybeans into tempe is a reflection of the harmony of Javanese society for making tempe is always done in pairs; Tempe is a commodity which is not only in the home industry, but also in the traditional market, which brought tempe to the market was a woman (formerly) with a scarf; Tempe is very close to human life, the bigger not only couples but also groups; Java slogan "Yen uripe resik tempene apik" that mean "only people who life is good (honest, sincere, willing to sacrifice) to produce good tempe", because people of Java believe that the cleanliness of the heart affect the quality of tempe made; Tempe also used rituals in life, such as getting salvation, getting balance; and tt the time of death, those who took care of the bodies treat 3 kinds of omelette, sambal goreng tempe, and mihun. Because the three foods are closest to human life. This means that if people do not have anything, the food is available. This is proof of Tempe was closely to human life

Stakeholder Workshop to finalize the 13 forms of UNESCO on Intangible cultural heritage 
According to the recognition of the ICHH from Indonesia, held by The Ministry of Education and Culture, Tempe has been decided as a ICHH from Indonesia in national list. That's the first step to nominate Tempe as ICHH to UNESCO. After that, the next step was completing the document of UNESCO. In order to implement the next step of submitting Tempe as ICHH to UNESCO, several activities have been conducted. As of now, Tempe has been enlisted in Ministry of Education and Culture as one of a national list Indonesia's Intangible Cultural Heritage. In order to submit tempe to UNESCO as Intangible Cultural Heritage, a form must be prepared and fulfilled, which will be done by committee and will be consulted with related stakeholders.

The document will legally be done by an expert team created by Ministry of Education and Culture. This team is consisted of staffs from Ministry of Education and Culture, Provincial Government, and Professional. There's 11 of these forms, which are:

a. ICH 01 Completing form for a possible inscription and assistance

b. b.ICH 02 Completing form for a possible inscription

c. ICH 03 Completing form for a possible selection

d. d.ICH 04 Completing form for international assistance from the intangible cultural heritage fund

e. ICH 05 Completing form for preparatory assistance for elaborating a nomination for inscription on the urgent safeguarding

f. ICH 06 Completing form for preparatory assistance for elaborating a proposal for the register of best safeguarding practices

g. g.ICH 07 Completing form for photo and video

h. h.ICH 08 Completing form report by a non-governmental organization accredited to act in an advisory capacity to the committee on its contribution to the implementation of the convention

i. ICH 09 Completing form request by a non-governmental organization accredited to be accredited to provide advisory services to the committee

j. ICH 10 Completing form report on the implementation of the convention and on the status of elements inscribed on the representative list of the intangible cultural heritage of humanity

k. k.ICH 11 Completing form report of an element inscribed on the list of intangible cultural heritage in need of urgent safeguarding
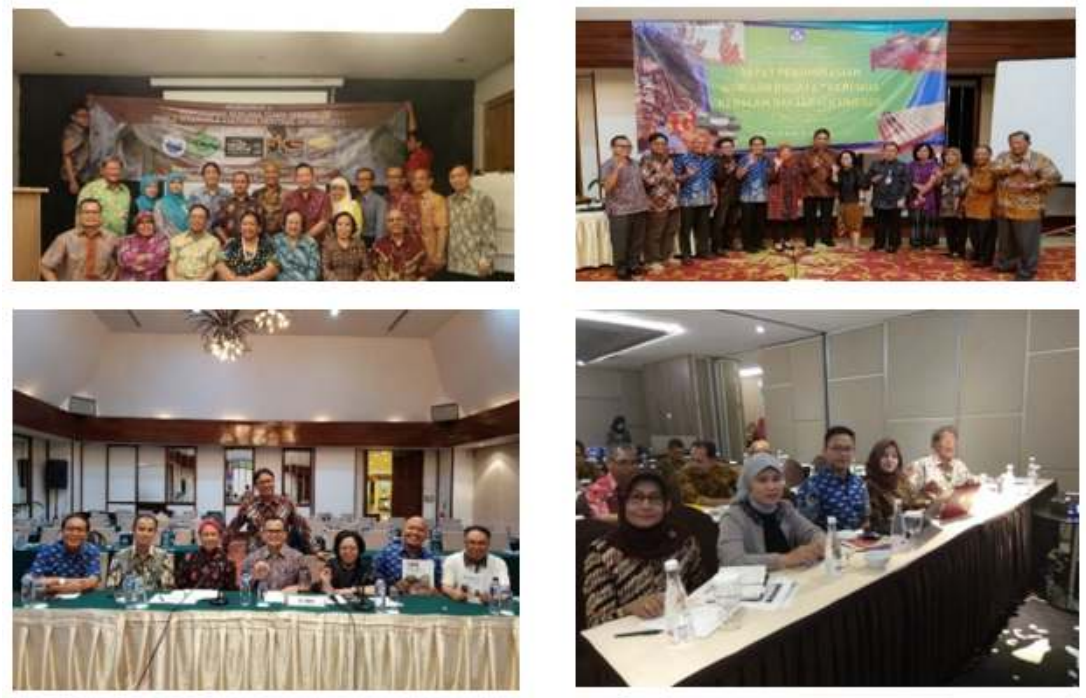

Figure 7. Stakeholder Workshop to finalize the 13 forms of UNESCO

Gain support from stakeholder, institution, and all elements 
As much as 22 related professional association, central government institutions, universities, tempe producers and consumers supported writenly that tempe should be proposed to be national list of intangible cultural heritage; and further to be intangible cultural heritage of UNESCO.
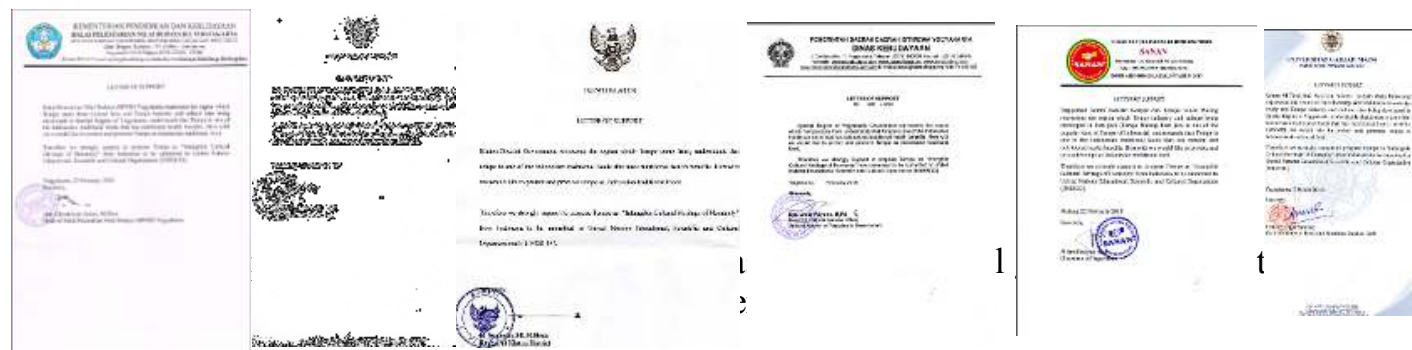

The final result of this activity was the Ministry of Education \& Culture formally launched that Tempe was included in the list of national list of intangible cultural heritage based on certificate number 60089/MPK.E/KB/2017.
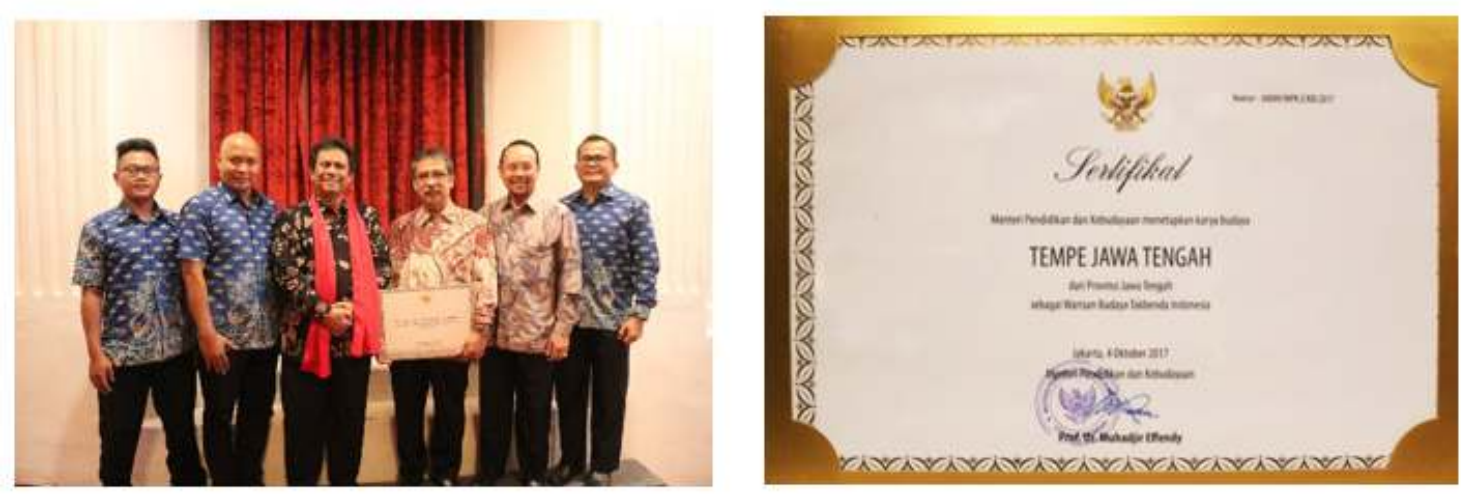

Figure 8. Tempe as a national list of ICHH of Indonesia based on certificate number 60089/MPK.E/KB/2017

\section{CONCLUSION}

In conclusion, tempe has been appointed as a national list of ICCH from Indonesia. This is as proof that tempe is Indonesian Indigenous Food and Culture.

\section{REFERENCES}

Bintari, S. H., Putriningtyas, N. D., Nugraheni, K., Widyastiti, N. S., Dharmana, E., \& Johan, A. (2015). Comparative Effect of Tempe and Soymilk on Fasting Blood Glucose, Insulin Level and Pancreatic Beta Cell Expression (Study on Streptozotocin-Induced Diabetic Rats).Pakistan Journal of Nutrition, 14(4), 239.

Statistics Indonesia. (2014). Statistik Indonesia : Statistical Yearbook of Indonesia 2014. Jakarta : Statistics Indonesia

Statistics Indonesia. (2015). Statistik Indonesia : Statistical Yearbook of Indonesia 2015. Jakarta : Statistics Indonesia 
Utari, D.M., Rimbawan, Riyadi, H., Muhilal, \& Purwantyastuti. (2011). Potency of Amino Acid in Tempeh for Improving Lipid Profile and Diabetes Mellitus. Jurnal Kesehatan Masyarakat Nasional Vol. 5, No. 4, Februari 2011 : 166-170

Wirawanti, I.W., Hardinsyah, Briawan, D.,\&Astawan, M. (2017). The effect of tempe drink intervention on low density lipoprotein decreasing. J. Gizi Pangan, Maret 2017, 12(1):9-16 